\title{
A Studying on Factors Affecting Decision to Use Smart Tourism Applications using extended TAM
}

\author{
NGUYEN TRAN HUNG \\ Thuongmai University, Hanoi \\ VIETNAM \\ LE HOANG ANH \\ Banking University HCMC, Ho Chi Minh City \\ VIETNAM \\ DO THI THU HIEN \\ Thuongmai University, Hanoi \\ VIETNAM \\ VU THI THUY HANG \\ Thuongmai University, Hanoi \\ VIETNAM
}

\begin{abstract}
The paper presented the theoretical exten ded accept new technology model (TAM), based on this theory and the results of previous studies, the research has built a model to study the factors impact the decision to use the sm art travel applications in $\mathrm{V}$ ietnam. The study identified the following factors: Perceived eas e of use, Perceived usefulness, Social im pact, Self-control, Information security concerns and Service quality affecting the decision to use s mart travel applications. The Hypothesis is tested through EFA discovery factor analysis, regression methods performed on SPSS software. From the results, the study proposes solutions to promote smart applications in Vietnam.
\end{abstract}

Key-Words: - Extended TAM model; EFA discovery factor; Smart tourism.

Received: November 18, 2019. Revised: April 8, 2020. Accepted: April 16, 2020. Published: April 30, 2020.

\section{Introduction}

A smart city is the appli cation of inf ormation and communication technology connecting sensors, high-speed wireless networks, large data processing to improve the quality of life in urban areas, improving the quality of service of the city. city government, reducing energy consum ption, effective management of natural resources. In general, the assessment of a smart city based on the level of intelligence of the infrastructure that affects transport, health, construction, energy, management, etc. Smart streets, need to build intelligent systems: intelligent transportation sy stem, smart tourism system, smart education sy stem, ... In which the smart tourism system is well-placed. In $\mathrm{m}$ any countries, the smart travel system is represented by smart travel applicati ons. Can understand sm art tourism is a tourism model built based on information and communication technology; help interaction, the close connection between managers, businesses and tourists, to im prove the quality of customer service, while making the management more convenient.

In Vietnam, there have been many cities and provinces applying smart tourism applications: Hanoi, Da Nang, Ninh Binh, Ho Chi Minh City. Besides, there are also se veral cities and provinces in the plan to apply smart tourism applications such as Tuyen Quang, Ba Ria - Vung Tau.

According to a survey of $\mathrm{Q} \& \mathrm{M}$ e Market Research Company published in June 2017, 88\% of tourists search for information online, of which, $35 \%$ regularly use the intern et to search for travel information. There are a variety of potential s mart tourism users in Vietnam. Therefore, the question is that the internet there are quite a lot of information pages on tourism and there may appear unorthodox websites, so the applic ation of smart travel applications has become indispensable in the era of industrial network 4.0. 
Accurate assessment of the factors affecting smart travel application decisions will be helpful for all three application providers (Hanoi Department of Tourism, Vietnam Posts and Teleco mmunications Group), Travel business businesses an $\mathrm{d}$ app users. Accurately measure the factors that influence the decision to use smart travel applications, help application providers develop their applications in the best way, meeting the needs of people. Thereby attracting more users to choose and use the smart travel application. On the user side, us ers have more access to the utilities that technology brings to tourism.

Among the provinces and cities that are applying smart tourism applications, Hanoi is the capital of Vietnam with $\mathrm{m}$ any famous tourist destinations. Specifically, Hanoi h as had po pular travel applications: Ha Boi City Guide, My Ha Hoi, Trip Hunter, Hanoi Departm ent of T ourism website, ... The research topic is aime d at students. Hanoi area. Therefore, the resear ch team decided to choose $t o$ deploy the topic: "Application of TAM (Technology acceptance model) to study the factors affecting the decision to use smart tourism applications in the context of Hanoi direction. to build a smart city".

\section{The Theory of Acceptance of Technology}

The Technology Acceptance Model (TAM ) developed by Davis (1989). The TAM adopts the TRA model because of the rel ationships to explain an individual's acceptable behaviour. TAM has considered as the powerfu 1 and meticulous way to represent the antecedent of $\mathrm{s}$ ystem usage through beliefs about two constr uct: 1) The Perceived Usefulness (PU) and 2) The Perceived Ease of Use (PEOU) combined of an information system (Davis, 1989, 1993; Davis et al., 1989, 1992). PU is defined as "the degree to which a person believ es that using a particular sy stem would enhance hi s or her job performance". PEOU is defined as "the degree to which a person believes that using a particular system would be free of effort"

The attitude toward using is depended by two other factors such as Perceived Usefulness (PU) and Perceived Ease of Use (PEOU). Perceived Usefulness is influenced by Perceived Ease of Use. On the other hand, both Perceived Usefulness and Perceived Ease of Us e are influenced by external variables (EV). Behavioural intentio $\mathrm{n}$ to use is determined by the attitude towards using the new system. Finally, behavio ural intention to use affect to actual use (Davis et al., 1989).

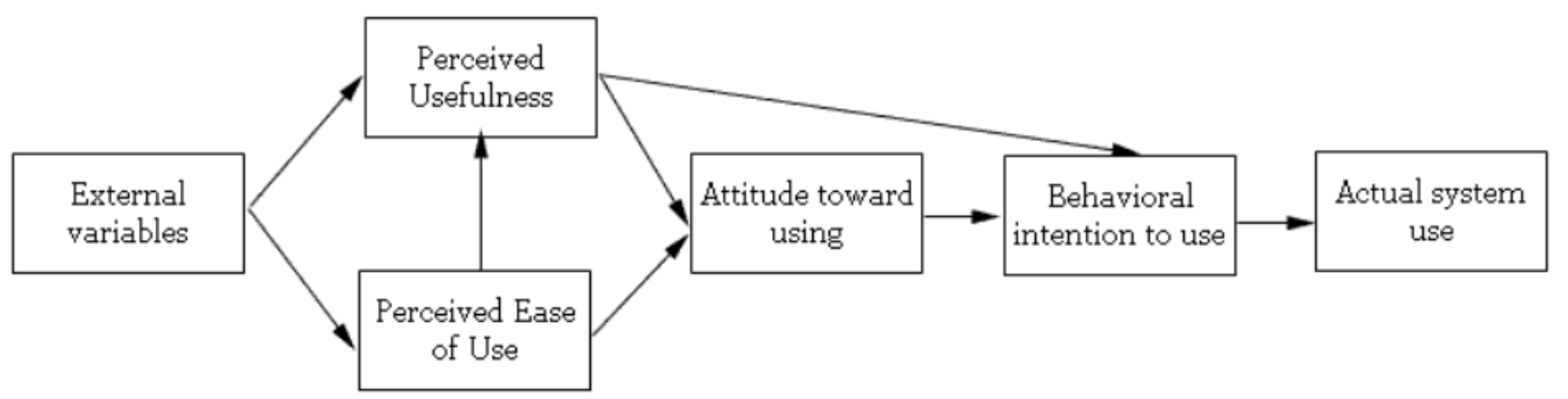

Figure 1. Technology Acceptance Model

Source: Davis et al. (1989)

Many previous types of resea rch have applied TAM that proves the role of this theory. Thus, in the research of Yang et al. (2007) , the author s conducted a survey questionnaire to collect citizen' perceived levels of their intention of E-tax. The constructs and questionnaire develop throug $\mathrm{h}$ that collected about technol ogy acceptance m odel and diffusion of innovation of articles in the last few years. The objects of the survey were the citizen who has exp erienced tax. The re sults of this study showed the suitable to appl y TAM in E-tax. Thus, the attitude and Perceived Usefulness have a direct influence on the construct behaviour intention, these results suitable with the c ontext of E-tax rese arch from other research such as Hung et al. (2006); Wu et al. (2005); and Chang et al, (2005). Moreover, the construct Perceived Us efulness and Perceived Ease of Use have a significantly positi ve effect on the attitude toward using $\mathrm{E}$-tax. This result proved consistent with the e mpirical research by Chang (2005) and Hung (2006). The study confirmed most of the TAM's conclusions in prio $r$ studies in applying other Information Technology. 
Although TAM has been widely applied to study on smart tourism field, but still meet with so me limitations such as TAM does not capture the characteristics that are $\mathrm{s}$ pecific to e-tourism. For instance, in the research of Sun et al. (2007), the authors stated that the ultimate goal of on-li ne Shopping is to entice consumers to shop online, $\mathrm{n}$ ot only be a ge neric information system. On the ot her hand, e-tourism is full of uncertainties. It is a reason for the need of adding more factors as antecedents of consumer acceptance. Thus, many studies have been carried out with extension factors.

TAM has been extended by the addition of other constructs such as co mputer self-efficacy Compeau \& Higgins, 1995), Internet self-efficacy (Igbaria \& Iivari, 1995; Eastin \& LaRose, 2000; Joo et al., 2000; Hsu \& Chiu, 2004a), subjective norm (Taylor \& Todd, 1995a; Venkatesh \& Davis, 2000 Bhattacherjee, 2000) or play fulness (Liu \& Arnett, 2000; Moon \& Kim, 2001; Hsu \& Chiu, 2004a).

In the previous study, Wixom and Todd (2005) stated that research ers have sought to extend TAM primarily in one of three following ways: (1) by introducing factors from related models, (2) b y introducing additional or a lternative belief factors, or (3) by examining antecedents and moderators of Perceived Usefulness and Perceived E ase of U se. On the othe $r$ hand, Sh ih (2004) developed an extended TAM model to predict consu mer acceptance of online shopping. The author hypothesized User Satisf action, Web Security \& Access Costs, and Percei ved Information Quality, Perceived System Quality, Perceived Services Quality are independent variables, Pikkarainen et al. (2004) studied consumer acceptance of Online Banking in Finland in the light of the TAM added with new variables such as security and privacy, perceived enjoyment, information on online banking, and quality of Internet connection.

Pikkarainen et al. (2004) studied consumer acceptance of online tourism in Finland by adopting the TAM a dded with new variables such a $\mathrm{s}$ perceived enjoyment, information on online tourism, security and privacy and quality of Internet connection. In the study in the context of Malay sia about internet banking, th e author examination of individual's perceived security and privacy and the Influence of this on their intention to use e-tourism by using an extension of the TAM, Lallmaham ood (2000) proposed many previous studies with the reason of e xtending TAM, in this resear ch, the author added perceived security and privacy as an independent variable beside Perceived Ease of Use and Perceived Usefulness.
Thus, the use of an extended TAM as a theoretical framework is adopted to e xamine the effect of an external variable on the inte ntion to use e-tourism. In addition to TAM being a widely used and proven model, other reasons for the adoption of this model are because TAM is si mple and etourism is an information system and an application used by many internet users.

\section{Research model}

Based on Davis' s TAM ( 1989) model combined with the results of prev ious studies b y other authors, the team proposed factors that influence the decision to use sm art travel applications of people. people in Hanoi. Ease of use is the degree of personal confidence in using the application that will bring $f$ reedom of freedo $m$ (Davis, 1989; Davis, 1993). Smart travel application is a new technology application, but this is the application on the phone or the website so users can use the application without much difficulty. Many studies are showing that ea se of use ha $\mathrm{s}$ an impact on users' new technolog y application (Bendegul Okumus \& Anil Bilgihan, 2013 ; Changsok Yoo, Shinhye Kwon, Hyunsoo Na \& Byenghee Chang, 2017; Davis, 1989). Therefore, the author proposes the hypothesis:

\section{H1: Perceived Ease of Use (SD) has a positive} effect on the decision to use (QD)

Perceptible usefulness is the perception of a customer concerning the potential advantages of their decision. This fact or has been studied in many studies involvin $g$ the application of new technologies. This is co nsistent with previous studies (Bendegul Okumus \& Anil Bilgihan, 2013; Changsok Yoo, Shi nhye Kwon, Hyunsoo Na \& Byenghee Chang, 2017 ; Davis, 1989). Therefore, the author proposes the hypothesis:

\section{H2: Perceptual usefulness (HI) has a positive} effect on use decision (QD)

Information quality and service quality are the two factors that can be considered as deciding whether or not users wi ll use the service of a provider. and services that affect user use of the service (Changsok Yoo, Shinhye Kwon, Hyunsoo $\mathrm{Na} \&$ Byenghee Chang, 2017; Le Qu ang Hung, 2017). The following 2 hy potheses have been added to the proposed model

H3: Information quality (TT) received has the same direction of use decision $(Q D)$

H4: Service quality (DV) has the same direction of use decision $(Q D)$

In addition to the above two variables, awareness of preference is also present in $\mathrm{m}$ any 
studies on the application of new technolo gy to know whether users feel like using the application (Bendegul Okumus \& Anil Bilgihan, 201 3; Changsok Yoo, Shi nhye Kwon, Hyunsoo Na \& Byenghee Chang, 2017)

\section{H5: Perception of preference (UT) has a positive} effect on use decision (QD)

The higher the self-control of people, th e more they are inclined to use new technology services or the autonomy positively affects the decision to use new technology services. Research on self-control influences previous use decisions (Bendegul Okumus \& Anil Bilgihan, 201 3). Therefore, propose hypotheses

H6: Self-reliance (LC) works in the same direction as use decision (QD)

Social influence or social norm s indicate a user is aware of the other person' s point of view about whether the person should use the ser vice or not [1]. Previously, there was also res earch showing that social influences infl uence users' decision to use services (Bendegul Okumus \& Anil Bilgihan, 2013)

\section{H7: Social influence (social) impact positively with use decision (QD)}

The technological barrier is the develop ment of technology that hinders the user 's easy use of the application; previous research has de monstrated that technological barriers affect the use of technology services. New (Bendegul Okum us \& Anil Bilgihan, 2013)

H8: Technological barrier (CN) has the opposite effect of usage decision (QD)

When applying new technology services, what users are $\mathrm{q}$ uite worried about is that their information is leaked out, so inform ation security factors also play an im portant role to help researchers apply. New technology com pletes its research paper (Changsok Yoo, Shinhy e Kwon, Hyunsoo Na \& Byenghee Chang, 2017)

H9: Information security (AT) has a positive impact on the decision to use (QD)

From the above assumptions, we have the model below:

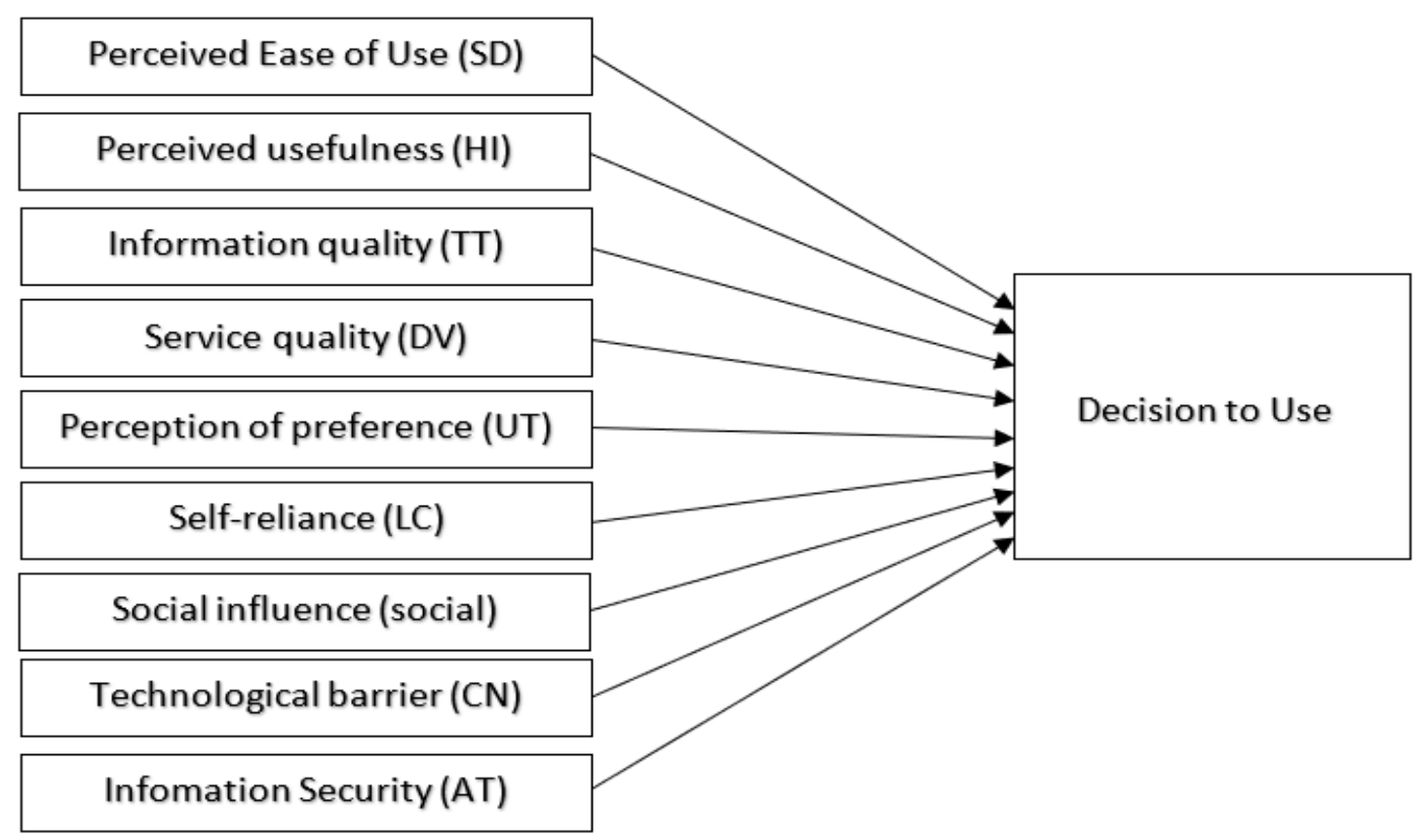

Figure 2. The proposed research model

Explain variables in the model has shown in appendix 1.

\section{Research Methods}

Questionnaire design: The study was conducted in Likert rank using 5 points.

A convenient sam pling method was used to survey residents using the smart travel application in Vietnam.
Data were collected by questionnaire, coded and processed by SPSS software, fro $m$ which the analysis was performed: Descriptive analysis, Cronbach's Alpha test, EFA discovery factor analysis, feedback analysis. convention.

275 questionnaires were given ou t. Then proceed to receive the answer sheet, clean the information, encode the neces sary information in 
the answer sheet, enter and analyze the data using SPSS 20.0 software.

The minimum sample size for exploratory factor analysis EFA is $n=5 m$, where $m$ is the num ber of questions in the paper (Hair et al., 1998) . For multivariate regression analysis, the minimum sample size is $n=50+8 m$, where $m$ is the number of independent factors (Tabachnicho Fidell, 1996).

\section{Experiment results}

\subsection{Test the reliability of the scale by Cronbach's Alpha coefficient}

The variables SD, HI, TT, DV, AT, XH, CN, LC, UT, and Q D were tested with a scale of Cronbach's Alpha.

In which: LC, QD variable Cronbach's Alpha coefficient is very high, respectively $0.834 ; 0.865$;
The variables HI, TT, DV, $\mathrm{XH}, \mathrm{CN}$, AT have Cronbach's Alpha coefficient, respectively, 0,790; $0.750 ; 0.775 ; 0.781 ; 0.764 ; 0.760$ are greater than 0.7

The variable SD has a Cronbach' coefficient of 0.6656 greater than 0.6 ;

The UT variable has a Cronbach's coefficient of 0.614 and has an item s Alpha correlation of the UT3 variable $<0.3$, so it excludes the UT3 variable from the observed variable when the UT variable has a Cronbach's Alpha coefficient of 0.754 .

On the other hand, all va riables (except UT3) have an item-total correlation $>0.3$. Therefore, remove the UT3 observation variable to perform EFA discovery factor analysis

EFA discovery factor analy sis. After the first analysis results:

\section{Table 1. Analysis results of KMO and Bartlett's Test}

\begin{tabular}{|c|c|c|}
\hline \multicolumn{3}{|l|}{ KMO and Bartlett's Test } \\
\hline \multicolumn{2}{|c|}{ Kaiser-Meyer-Olkin Measure of Sampling Adequacy. } & 0.873 \\
\hline \multirow[t]{3}{*}{ Bartlett's Test of Sphericity } & Approx. Chi-Square & 2996.304 \\
\hline & Df & 406 \\
\hline & Sig. & 0.000 \\
\hline
\end{tabular}

Table 2. Rotated Component Matrix

(Source: SPSS data analysis results)

\begin{tabular}{|c|c|c|c|c|c|c|c|c|}
\hline & \multicolumn{8}{|c|}{ Component } \\
\hline & 1 & 2 & 3 & 4 & 5 & 6 & 7 & 8 \\
\hline HI2 & .746 & & & & & & & \\
\hline HI1 & .743 & & & & & & & \\
\hline UT1 & .645 & & & & & & & \\
\hline HI3 & .586 & & & & & & & \\
\hline HI4 & .583 & & & & & & & \\
\hline UT2 & .566 & & & & & & & \\
\hline DV3 & & .776 & & & & & & \\
\hline DV1 & & .706 & & & & & & \\
\hline DV2 & & .681 & & & & & & \\
\hline DV4 & & .503 & & & & & & \\
\hline LC2 & & & .707 & & & & & \\
\hline LC3 & & & .686 & & & & & \\
\hline LC4 & & & .673 & & & & & \\
\hline LC1 & & & & & & & & \\
\hline XH2 & & & & .795 & & & & \\
\hline XH3 & & & & .752 & & & & \\
\hline XH1 & & & & .685 & & & & \\
\hline
\end{tabular}




\begin{tabular}{|l|l|l|l|l|l|l|l|l|}
\hline TT2 & & & & & .808 & & & \\
\hline TT3 & & & & & .673 & & & \\
\hline TT1 & & & & & .659 & & & \\
\hline AT1 & & & & & & .785 & & \\
\hline AT2 & & & & & & .781 & & \\
\hline AT3 & & & & & & .587 & & \\
\hline CN2 & & & & & & & .797 & \\
\hline CN1 & & & & & & & .773 & \\
\hline CN3 & & & & & & & .594 & \\
\hline SD3 & & & & & & & & \\
\hline SD2 & & & & & & & & \\
\hline SD1 & & & & & & & & .501 \\
\hline
\end{tabular}

$\mathrm{KMO}$ index results $>0.5$ and Sig. $\quad=0.000$ statistically significant, the variables model are correlated.

Table 2 sho ws that all $\mathrm{v}$ ariables in the groups have values greater tha $n \quad 0.5$ and reach reli able values. And for the scale to have statistically significant variables, it is necessary to group:

Group 1 includes the variables: TT1, TT2, TT3;

Group 2 inc ludes variables: DV1, DV2, DV3, DV4;

Group 3 includes variables: AT1, AT2, AT3;

Group 4 includes variables: SD1, SD2, SD3;

Group 5 includes variables: LC2, LC3, LC4;

Group 6 includes variables: HI1, HI2, HI3, HI4;

Group 7 includes the variables: $\mathrm{XH1}, \mathrm{XH}, \mathrm{XH} 3$;

Group 8 includes the variables: CN1, CN2, CN3;

Based on the Total Vari ance Explained table, dividing into 8 gro ups explains $66.530 \%$ of the variation of the model.
(Source: SPSS data analysis results)

All Communalities of observed variables have values greater than 0.4 . With threshold criteria of Communalities value $>0.4$ is acceptable.

\subsection{Pearson correlation test results}

Based on Cronbach's Alpha test results and EFA discovery factor analy sis remove TT4 variables and create representative factors:

$$
\begin{aligned}
& \mathrm{SD}=\text { Mean }(\mathrm{SD} 1, \mathrm{SD} 2, \mathrm{SD} 3) \text {; } \\
& \mathrm{HI}=\text { Mean (HI1, HI2, HI3, HI4); } \\
& \text { TT = Mean (TT1, TT2, TT3); } \\
& \text { DV }=\text { Mean (DV1, DV2, DV3, DV4); } \\
& \mathrm{AT}=\text { Mean }(\mathrm{AT} 1, \mathrm{AT} 2, \mathrm{AT} 3) \text {; } \\
& \mathrm{LC}=\text { Mean }(\mathrm{LC} 2, \mathrm{LC} 3, \mathrm{LC} 4) \text {; } \\
& \mathrm{XH}=\text { Mean (XH1, XH2, XH3); } \\
& \mathrm{CN}=\text { Mean }(\mathrm{CN} 1, \mathrm{CN} 2 ; \mathrm{CN} 3) \text {; } \\
& \mathrm{QD}=\text { Mean }(\mathrm{QD} 1, \mathrm{QD} 2, \mathrm{QD} 3, \mathrm{QD} 4)
\end{aligned}
$$

Table 3. Pearson correlation test results (Correlations)

\begin{tabular}{|l|l|l|l|l|l|l|l|l|l|l|}
\hline \multicolumn{2}{|c|}{} & QD & AT & SD & LC & XH & HI & CN & T & V \\
\hline QD & $\begin{array}{l}\text { Pearson } \\
\text { Correlation }\end{array}$ & 1 & $.509^{* *}$ & $.366^{* *}$ & $.610^{* *}$ & $.565^{* *}$ & $.620^{* *}$ & $.461^{* *}$ & $.418^{* *}$ & $.567^{* *}$ \\
\cline { 2 - 10 } & $\begin{array}{l}\text { Sig. } \\
\text { tailed) }\end{array}$ & & 000 & .000 & 000 & .000 & 000 & 000 & .000 & 000 \\
\cline { 2 - 10 } & $\mathrm{N}$ & 230 & 230 & 230 & 230 & 230 & 230 & 230 & 230 & 230 \\
\hline
\end{tabular}

Pearson correlation test shows the correlation between each independen $t$ variable in the $m$ odel and the dep endent variable. This test is done through the calculation of Pearson's correlation coefficient. Pearson's correlation coefficient is the covariance of the two $\mathrm{v}$ ariables divided $\mathrm{b} y$ the product of their standard deviations. Si g value. of observed variables SD, HI, LC, DV, AT, CN, TT,
(Source: SPSS data analysis results) $\mathrm{XH}$ are less than 0.05 which means that the independent variable co rrelates the dependent variable. Results of building a single linear regression model. 
Table 4. Model summary results (Model Summary)

\begin{tabular}{|c|c|c|c|c|c|c|c|c|c|c|}
\hline Model & $\mathrm{R}$ & $\begin{array}{c}\mathrm{R} \\
\text { Square }\end{array}$ & $\begin{array}{c}\text { Adjusted } \\
\mathrm{R} \\
\text { Square }\end{array}$ & $\begin{array}{c}\text { Etr. } \\
\text { the } \\
\text { Estimate }\end{array}$ & $\begin{array}{c}\mathrm{R} \\
\text { Square } \\
\text { Change }\end{array}$ & $\begin{array}{c}\mathrm{F} \\
\text { Change }\end{array}$ & $\mathrm{df1}$ & df2 & $\begin{array}{c}\text { Sig. F } \\
\text { Change }\end{array}$ & $\begin{array}{c}\text { Durbin- } \\
\text { Watson }\end{array}$ \\
\hline 1 & $.787^{\mathrm{a}}$ & .619 & .606 & .462 & .619 & 44.732 & 8 & 221 & .000 & 1.982 \\
\hline
\end{tabular}

a. Predictors: (Constant), CN, SD, DV, XH, AT, TT, LC, HI

b. Dependent Variable: QD

Adjusted R Square ( $\mathrm{R}$ square correct ed) reflects the influence of the independent variables on th $\mathrm{e}$ dependent variable. Here, 8 independent variables are included in the effect of $61.93 \%$ of the change of the dependent variable, the rest is $\mathrm{d}$ ue to nonmodel variables and rand om errors. The Durbin-
(Source: SPSS data analysis results) Watson value of 1,9 82 has a value of approximately 2, so $\mathrm{t}$ here is no first-order correlation.

Table 5. ANOVA variance analysis results

\begin{tabular}{|c|l|l|l|l|l|l|}
\hline \multicolumn{2}{|c|}{ Model } & Sum of Squares & $\mathrm{df}$ & Mean Square & F & Sig. \\
\hline \multirow{3}{*}{1} & Regression & 76.863 & 8 & 9.608 & 44.943 & $.000^{\mathrm{b}}$ \\
\cline { 2 - 7 } & Residual & 47.245 & 221 & .214 & & \\
\cline { 2 - 7 } & Total & 124.108 & 229 & & & \\
\hline
\end{tabular}

a. Dependent Variable: QD

b. Predictors: (Constant), CN, SD, DV, XH, AT, TT, LC, HI

Sig value. of test $\mathrm{F}$ is $0.000<0.05$. Thus, the linear

(Source: SPSS data analysis results) regression model is consistent with the overall.

Table 6. Coefficients results

\begin{tabular}{|c|c|c|c|c|c|c|c|c|c|c|}
\hline \multirow{2}{*}{ Model } & \multicolumn{2}{|c|}{$\begin{array}{l}\text { Unstandardized } \\
\text { Coefficients }\end{array}$} & \multirow{2}{*}{$\begin{array}{c}\begin{array}{c}\text { Standardized } \\
\text { Coefficients }\end{array} \\
\text { Beta }\end{array}$} & \multirow{2}{*}{$\mathrm{t}$} & \multirow{2}{*}{ Sig. } & \multicolumn{3}{|c|}{ Correlations } & \multicolumn{2}{|c|}{$\begin{array}{l}\text { Collinearity } \\
\text { Statistics }\end{array}$} \\
\hline & B & Std. Error & & & & $\begin{array}{l}\text { Zero- } \\
\text { order }\end{array}$ & Partial & Part & Tolerance & VIF \\
\hline (Constant) & -.380 & .245 & & -1.555 & .121 & & & & & \\
\hline $\mathrm{AT}$ & .121 & .044 & .144 & 2.737 & .007 & 0.513 & 0.189 & 0.119 & .624 & 1.602 \\
\hline SD & .144 & .057 & .116 & 2.510 & .013 & 0.367 & 0.169 & 0.106 & .805 & 1.242 \\
\hline $\mathrm{LC}$ & .156 & .053 & .167 & 2.944 & .004 & 0.610 & 0.196 & 0.124 & .537 & 1.861 \\
\hline $\mathrm{HI}$ & .233 & .061 & .218 & 3.804 & .000 & 0.618 & 0.241 & 0.154 & .527 & 1.899 \\
\hline $\mathrm{XH}$ & .197 & .044 & .229 & 4.445 & .000 & 0.563 & 0.279 & 0.180 & .650 & 1.538 \\
\hline TT & -.023 & .054 & -.022 & -.430 & .667 & 0.421 & -0.022 & -0.013 & .634 & 1.577 \\
\hline DV & .267 & .066 & .219 & 4.053 & .000 & 0.566 & 0.259 & 0.166 & .592 & 1.688 \\
\hline
\end{tabular}




\begin{tabular}{|l|l|l|l|l|l|l|l|l|l|l|}
\hline $\mathrm{CN}$ & .044 & .046 & .050 & .973 & .331 & 0.462 & 0.067 & 0.042 & .643 & 1.555 \\
\hline
\end{tabular}

a. Dependent Variable: QD

For t-tests of each inde pendent variable, Sig value. less than or equal to 0.05 means that variable has a meaning in the model, whereas Sig. greater than 0.05 , that independent variable should be removed. So in this model, only variables $\mathrm{AT}, \mathrm{SD}$, LC, HI, XH, DV are retained.

Beta normalized regression coefficients, a mong all regression coefficients, the independent variable with the lar gest Beta, that variable $h$ as the most
(Source: SPSS data analysis results) influence on the change of the dependent variable. Therefore, the SD variable has the most influence on the change of the QD dependent variable.

After removing TT variable, running t he model again, we get the foll owing result: $t$ he significant value of the $\mathrm{CN}$ variable is $0.346>0.05$, so we need to remove the $\mathrm{CN}$ variable.

After eliminating the $\mathrm{CN}$ variable, we get the following result:

Table 7. Coefficients

\begin{tabular}{|c|c|c|c|c|c|c|c|c|c|c|c|}
\hline & \multirow{2}{*}{ Model } & \multicolumn{2}{|c|}{$\begin{array}{c}\text { Unstandardized } \\
\text { Coefficients }\end{array}$} & \multirow{2}{*}{$\begin{array}{c}\text { Standardized } \\
\text { Coefficients } \\
\text { Beta }\end{array}$} & \multirow{2}{*}{$\mathrm{t}$} & \multirow{2}{*}{ Sig. } & \multicolumn{3}{|c|}{ Correlations } & \multicolumn{2}{|c|}{$\begin{array}{c}\text { Collinearity } \\
\text { Statistics }\end{array}$} \\
\hline & & B & $\begin{array}{l}\text { Std. } \\
\text { Error }\end{array}$ & & & & $\begin{array}{l}\text { Zero- } \\
\text { order }\end{array}$ & Partial & Part & Tolerance & VIF \\
\hline \multirow{7}{*}{1} & Constant & -.395 & .243 & & -1.621 & .106 & & & & & \\
\hline & AT & .119 & .038 & .150 & 3.115 & .002 & 0.513 & 0.222 & 0.141 & .744 & 1.344 \\
\hline & $\mathrm{LC}$ & .151 & .053 & .161 & 2.839 & .005 & 0.610 & 0.202 & 0.128 & .533 & 1.875 \\
\hline & SD & .141 & .055 & .114 & 2.548 & .012 & 0.367 & 0.166 & 0.104 & .860 & 1.163 \\
\hline & $\mathrm{XH}$ & .216 & .042 & .251 & 5.165 & .000 & 0.563 & 0.295 & 0.191 & .727 & 1.375 \\
\hline & $\mathrm{HI}$ & .237 & .060 & .221 & 3.951 & .000 & 0.618 & 0.242 & 0.155 & .549 & 1.822 \\
\hline & DV & .268 & .062 & .219 & 4.333 & .000 & 0.566 & 0.278 & 0.179 & .672 & 1.489 \\
\hline
\end{tabular}

a. Dependent Variable: QD

The table shows that Sig values of each boundary are $>0.05, \mathrm{~s}$ o it is possible to conclude that all variables affect the QD dependent variable.

Specifically, the influence of the factors on the QD is as follows:

$$
\begin{aligned}
& \mathrm{QD}=0.150 * \mathrm{AT}+0.111 \mathrm{SD}+0.161 * \mathrm{LC}+ \\
& 0.221 * \mathrm{HI}+0.251 * \mathrm{XH}+0.219 * \mathrm{DV}
\end{aligned}
$$

Thus, the factors AT, SD, LC, HI, XH, DV have the same directional effe ct, when inc reasing by 1 unit, the average value of the QD factor increases by $0.150 ; 0.1114 ; 0.161 ; 0.221 ; 0.251 ; 0.219$ units.

For research projects with a model combined with a questionnaire using the Likert scale, VIF $<2$ will not have multiple collinearities between independent variables. The above study did not meet the requirement of multicollinearity.
Histogram normalized residual frequency chart

The remainder may not follow the norm al distribution for reasons such as: Using the wron $g$ model, the variance is not a constant, the number of residuals is not sufficient for analysis, etc. We ne ed to conduct many different surveys. The simplest way to investigate is to build a histogram of the histogram remainder below. 


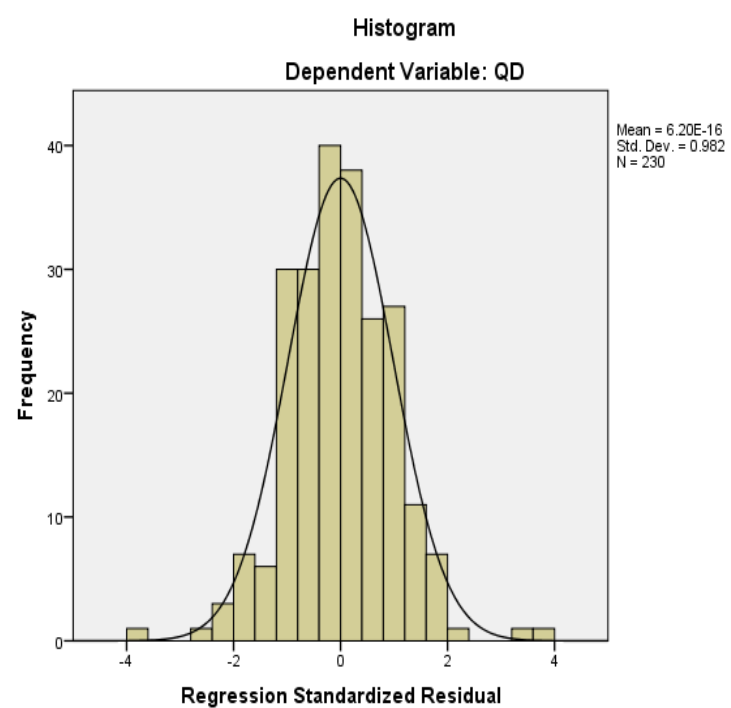

Figure 3. Histogram normalized residual frequency chart

(Source: SPSS data analysis results)

From the ch art shows, a standard distribution curve is superimposed on the frequency chart. This curve has a symmetrical form that fit $s$ the graph form of the $\mathrm{n}$ ormal distribution. The mean value is close to 0 , the standard deviation is 0.982 close to 1 , so we can say the standard approximation distribution. Therefore, it can be concluded that: Assuming the normal distribution of the residual is not violate.

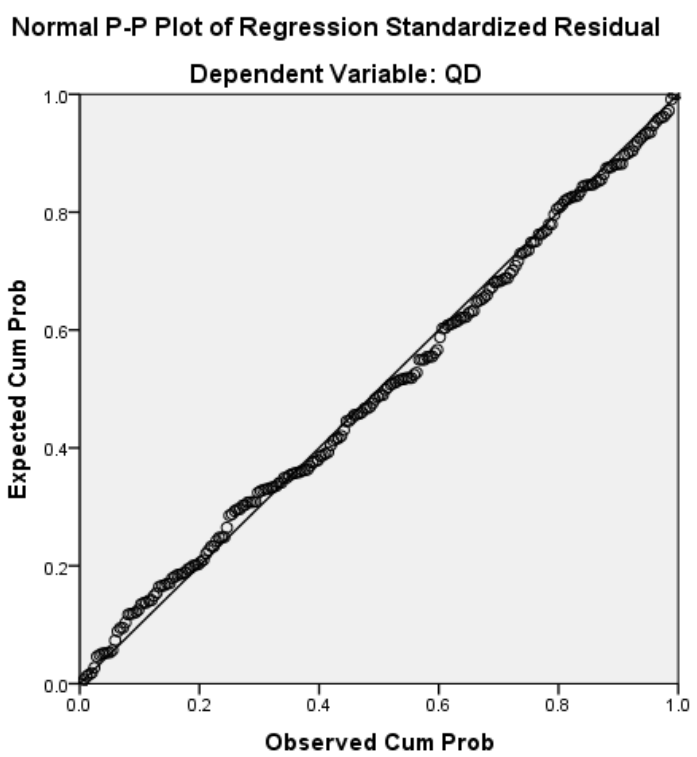

Figure 4. Normalization graph of Normal P-P Plot

(Source: SPSS data analysis results)

With P-P Pl ot, the percentile points in the distribution of the remai nder will focus into a diagonal line, thus not violating the regression assumption of residual calibration.
Scatter Plot scatter plots between stand ardized residuals and normalized predictive values help us detect whether existing data violates the linear relationship assumption. Represents the Standardized Residual value on the horizontal axis and the Predicted Value on the vertical axis.

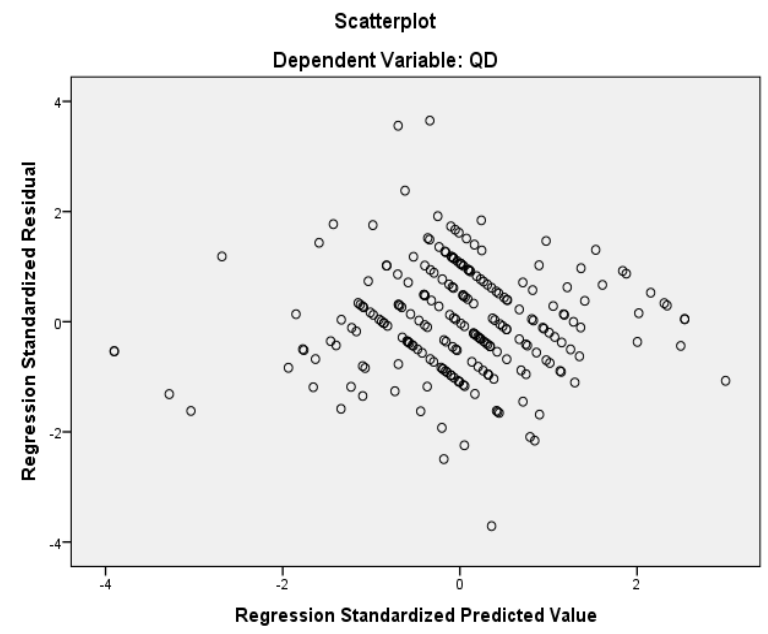

Figure 5. Scatter Plot chart tests the linear contact assumption.

(Source: SPSS data analysis results)

The output graph, the distribution points of the remainder if there are forms: Parab olic graph, Cubic graph or other non-linear graph forms, the data violates the assu mption of a linear relation. count. Looking at the graph, we can see that the standardized residual has not changed in any order against the s tandardized predicted value. Hen ce the assumption of linear contact is not violated.

\section{Conclusion and propose solutions}

\subsection{Conclusion:}

Such data analy sis results show that: perceived usefulness, perceived ease of use, social influence, information-related concerns, service quality, and autonomy affect the decision. inten ds to use the smart travel application of people in Hanoi but to varying degrees. In particular, the Social influence factor has the strongest influence on the decision to use s mart travel applications of the people in Hanoi and the Factor in the perceived e ase of use has the least influence on the decision to use Smart travel application. The Social Influence factor (Social) is the one that has the most influence on the decision to use, which supports the hypothesis of Bendegul Okumus \& Anil Bilgihan (2013). The Quality of Service (DV) factor influences the decision to share smart travel applications following the research by Changsok Yoo, Shinhye Kwon, Hyunsoo Na \& Byenghee Chang (20 17) 
and Le Quang Hung ( 2017). The factors HI and SD influence the de cision to use completely consistent with the TA M model (Davis, 1989; Davis, 1993); Bendegul Okumus \& Anil Bilgihan (2013), Changsok Yoo, Shinh ye Kwon, Hyunsoo $\mathrm{Na} \&$ By enghee Chang (2017) wit h previous IT studies. The influence of Information Security (AT) factor is consistent with the resear ch of Changsok Yoo, Shi nhye Kwon, Hyunsoo Na \& Byenghee Chang (2017).

\subsection{Proposed Solutions}

From the $r$ esearch results, it shows that the objective assessments for the developm ent of smart tourism applications in the present contribute to Vietnam towards buildi ng a sm art city. To develop smart travel appl ications in Vietnam, the application pro vider should pay attention, focus on im proving the following main factors: Quality of infor mation and services; Perceived usefulness; S ocial influence; Safety information. As follows:

Firstly, Social I mpact factor is one of the factors that greatly influence the decis ion to use smart travel applications of people in Vietnam, so the application provider should state heighten th e importance of this factor by implementing the following solution: (1) Through various channels such as television, social networks (especially social networks because of the access to the period of industrial revolution 4.0 , users tend to access information through social networks a lot. $\mathrm{m}$ ore), ... application vendors need to convey the message of the substitution of sm art travel apps co mpared to traditional travel. (2) Create opportunities for customers to increase the opportunit $y$ to experience the application before deciding to use it by expanding the free wifi sy stem (currently on the edge of Hoan Kiem Lake and some place $s$ already having wifi s ystem free). Particularly needed is the $\mathrm{i}$ mpact on pioneering custo mer groups that use the appl ication to demonstrate technological advancements. When the prophylactic customer group has a good assessment of the usefulness of the application, it is also the best signal to broadcast and transmit the most objective information to entice the rem aining customer groups to use the application.

Secondly, the Quality of Service factor, the results show that this factor has a lot of influence on the decision to use the smart travel application. (1) It is nece ssary to focus on im proving the core benefit of the smart travel application, which is a utility service that can be accessed any time, anywhere, making users feel more convenient and easier than the form. (2) Listen to feedback about the quality of customer applications $b$ y different channels such as feedback directly via the web, applications or hotlines, .. or through research surveys. From there, make appropriate plans to adjust and i mprove service quality to meet user needs.

Finally, Information Security Concern factor has also been shown to influence users' decision to use smart travel apps. The application that vendors need to bui ld trust with customers that their information provided to ap plication systems is not leaked out.

\subsection{Future Research}

Future studies may apply the procedure carried out by this study for a larger sa mple size. Doing this will make the results more general. Besides, the independent variables in this model only explain $61.9 \%$ of the variation of the dependent variable. Therefore, future studies can add other independent variables to the model to obtain new results.

\section{References}

[1]. Bendegul Okum us \& Anil Bilgihan (2013), "Proposing a model to test smartphone users"

[2]. Changsok Yoo, Shinhye Kwon, Hy unsoo Na và Byenghee Chang (2017) " Factors Affecting the Adoption of Gamified Smart Tourism Applications: An Integrative Approach"

[3]. Davis, F.D., (1989), Perceived usefulness, perceived ease of use and user acceptance of information technology", MIS Quarterly

[4]. Itsikoglou, Manolis K. Chat zis, Vassillis Panagiotopoulos (2013), "Factors Affecting Consumer Intention to use Internet for Food Shopping".

[5]. Lederer, A.L.; Maupin, D.J.; S ena, M.P.; Zhuang, Y. (2000), The technology acceptance model and the World WideWeb. Decis. Support Syst.

[6]. Liao, Z.; Cheung, M.T. (2001), Internet-based e-shopping and consumer attitudes: An empirical study. Inf. Manag.

[7]. M. Sajid Khan et al (2017), Smart City and Smart Tourism: A Case of Dubai

[8]. Hair, J.F., Black, W.C., Babin, B.J., Anderson, R.E. \& Tatham , R,L (2006 , Mutilvariate Data Analy sis 6th ed, Upper Saddle River NJ, Prentice - Hall.

[9]. Klopping, I, M. \& Mackinney, E. (2004), "Extending the techology acceptanc e model 
an the task - technolog y fit model to consumer e-commerce", Information Technology, Learning and Performance Journal

[10]. Kue, Y.F., \& Yen, S. N. (2009), "Towards an understanding of the behavioral
[11] Hee Seo Lee1, Taek Gyeom Kim \& Ji Youn Choi (2012), "A Study on the Factors Affecting Smart Phone Application Accept.

[12] Namho Chung và Heejeong Han (2015), "Tourists' Intention to Visit Destination: Role of Augmented Reality Applications for Heritage Site".

\section{Appendix 1. Explain variables in the model}

\begin{tabular}{|c|c|c|}
\hline I. & Perceived ease of use & Refer \\
\hline SD1 & You can learn how to use the application easily & \multirow{3}{*}{ Davis (1989), Davis (1993) } \\
\hline $\mathrm{SD} 2$ & $\begin{array}{l}\text { When interacting with the application you find it easy to } \\
\text { understand }\end{array}$ & \\
\hline SD3 & You find the smart travel app easy to use & \\
\hline \multicolumn{3}{|c|}{ Perceived usefulness } \\
\hline HI1 & $\begin{array}{l}\text { You find the use of smart travel apps very helpful for you in } \\
\text { providing travel information }\end{array}$ & \multirow{4}{*}{ Davis (1989), Davis (1993) } \\
\hline HI2 & $\begin{array}{l}\text { Smart travel application increases the efficiency of travel } \\
\text { activities, can be used anytime, anywhere }\end{array}$ & \\
\hline HI3 & $\begin{array}{l}\text { You find content provided through the smart travel app to } \\
\text { be useful to you }\end{array}$ & \\
\hline HI4 & $\begin{array}{l}\text { Overall, you consider the smart travel app a valuable service } \\
\text { to you }\end{array}$ & \\
\hline \multicolumn{3}{|c|}{ III. Information quality } \\
\hline TT1 & $\begin{array}{l}\text { The information provided from the smart travel application } \\
\text { is accurate }\end{array}$ & \multirow{3}{*}{$\begin{array}{l}\text { Changsok Yoo, Shinhye Kwon, } \\
\text { Hyunsoo Na \& Byenghee } \\
\text { Chang (2017) }\end{array}$} \\
\hline TT2 & $\begin{array}{l}\text { Information from the supplier about a satisfactory } \\
\text { application }\end{array}$ & \\
\hline TT3 & $\begin{array}{l}\text { Easily refer to the parameters of the smart travel application } \\
\text { through different forms whenever you want (app on phone, } \\
\text { web, ...) }\end{array}$ & \\
\hline \multicolumn{3}{|c|}{ IV. Service quality } \\
\hline DV1 & $\begin{array}{l}\text { The application provider fulfills its commitment to quality } \\
\text { of service }\end{array}$ & \multirow{4}{*}{ Le Quang Hung (2017) } \\
\hline DV2 & $\begin{array}{l}\text { Smart travel application of the provider of many core } \\
\text { services }\end{array}$ & \\
\hline DV3 & You think the provider will provide the service as expected & \\
\hline DV4 & $\begin{array}{l}\text { The smart travel app provider always provides services } \\
\text { quickly }\end{array}$ & \\
\hline \multicolumn{3}{|c|}{ V. Perception of preference } \\
\hline UT1 & You find it interesting to use the application & \multirow{3}{*}{$\begin{array}{l}\text { Bendegul Okumus \& Anil } \\
\text { Bilgihan (2013) }\end{array}$} \\
\hline UT2 & Smart travel app brings you the favor & \\
\hline UT3 & You use the app to kill time & \\
\hline \multicolumn{3}{|c|}{ VI. Self-reliance } \\
\hline LC1 & $\begin{array}{l}\text { You can use the app to search for travel information if } \\
\text { you've used the same app before }\end{array}$ & \multirow{4}{*}{$\begin{array}{l}\text { Bendegul Okumus \& Anil } \\
\text { Bilgihan (2013) }\end{array}$} \\
\hline LC2 & $\begin{array}{l}\text { You can use the app to search for travel information if } \\
\text { someone guides you to use it }\end{array}$ & \\
\hline LC3 & $\begin{array}{l}\text { You can use the app to search for travel information if you } \\
\text { have time to try it out }\end{array}$ & \\
\hline LC4 & $\begin{array}{l}\text { You can use the application to search for travel information } \\
\text { if you can afford the objects of travel such as entrance } \\
\text { tickets, food, reservations ... }\end{array}$ & \\
\hline
\end{tabular}




\begin{tabular}{|c|c|c|}
\hline \multicolumn{3}{|c|}{ VII. Social influence } \\
\hline XH1 & $\begin{array}{l}\text { You use the app because your friends also use it and you } \\
\text { want to belong to that group }\end{array}$ & \multirow{3}{*}{$\begin{array}{l}\text { Bendegul Okumus \& Anil } \\
\text { Bilgihan (2013) }\end{array}$} \\
\hline $\mathrm{XH} 2$ & Using the app also reflects my personality to others & \\
\hline XH3 & $\begin{array}{l}\text { According to your loved ones, you should use the smart } \\
\text { travel app }\end{array}$ & \\
\hline \multicolumn{3}{|c|}{ VIII. Technological barriers } \\
\hline CN1 & You find installing this application difficult for yourself & \multirow{3}{*}{$\begin{array}{l}\text { Bendegul Okumus \& Anil } \\
\text { Bilgihan (2013) }\end{array}$} \\
\hline $\mathrm{CN} 2$ & $\begin{array}{l}\text { Differences from traditional travel forms affect your use of } \\
\text { smart travel apps }\end{array}$ & \\
\hline $\mathrm{CN} 3$ & $\begin{array}{l}\text { The slow performance of smart travel websites or apps } \\
\text { affects your decision to use the smart travel app. }\end{array}$ & \\
\hline \multicolumn{3}{|c|}{ IX. Concerned about information security } \\
\hline AT1 & You are afraid your information will be collected & \multirow{3}{*}{$\begin{array}{l}\text { Changsok Yoo, Shinhye Kwon, } \\
\text { Hyunsoo Na \& Byenghee } \\
\text { Chang (2017) }\end{array}$} \\
\hline AT2 & $\begin{array}{l}\text { Logging in to smart travel websites or apps with personal } \\
\text { information affects your intention to use the app }\end{array}$ & \\
\hline AT3 & $\begin{array}{l}\text { You use virtual credentials to log in to smart travel websites } \\
\text { or apps }\end{array}$ & \\
\hline \multicolumn{3}{|c|}{ Decided to use } \\
\hline QD1 & $\begin{array}{l}\text { In general, the smart travel application of the current } \\
\text { application delivery forms makes me feel satisfied }\end{array}$ & \multirow{4}{*}{$\begin{array}{l}\text { Changsok Yoo, Shinhye Kwon, } \\
\text { Hyunsoo Na \& Byenghee } \\
\text { Chang (2017) }\end{array}$} \\
\hline QD2 & Using smart travel apps is my right decision & \\
\hline QD3 & I enjoy using the $4 \mathrm{G}$ smart travel app for my activities & \\
\hline QD4 & $\begin{array}{l}\text { I will continue to use the smart travel application in the } \\
\text { future }\end{array}$ & \\
\hline
\end{tabular}

